\title{
INTEGRASI METODE ANP DAN TOPSIS DALAM EVALUASI KINERJA SUPPLIER DAN PENENTUAN PRIORITAS SUPPLIER BAHAN BAKU UTAMA CETAK KORAN PADA PT MASSCOM GRAPHY SEMARANG
}

\author{
Darminto Pujotomo*), Nia Budi Puspitasari, Dwi Rizkiyani \\ Program Studi Teknik Industri Universitas Diponegoro
}

(Received: August 9, 2016 / Accepted: December 21, 2016)

\begin{abstract}
ABSTRAK
Salah satu faktor yang mempengaruhi kinerja perusahaan adalah keberadaan supplier yang berperan sebagai pemasok kebutuhan atau penyedia bahan baku. PT Masscom Graphy Semarang merupakan perusahaan percetakan yang telah menjalin kerjasama dengan beberapa supplier untuk menjamin kelangsungan produksinya. Oleh karena itu evaluasi kinerja supplier sangat penting dilakukan oleh perusahaan untuk mendapatkan supplier yang handal dalam memasok bahan baku. Tujuan dalam penelitian ini adalah mengidentifikasi kriteria evaluasi kinerja supplier dan penentuan prioritas supplier yang sesuai dengan kebutuhan perusahaan, dan menentukan urutan prioritas supplier untuk bahan baku utama cetak koran. Terdapat 17 subkriteria yang digunakan dalam evaluasi kinerja supplier dan penentuan prioritas supplier. Metode Analytical Network Process (ANP) dapat dijadikan alternatif untuk suatu permasalahan yang memiliki banyak subkriteria yang saling berkaitan dalam pengambilan keputusan. Selanjutnya metode Technique For Orders Preference by Similarity to Ideal Solution (TOPSIS) digunakan untuk perankingan supplier. Berdasarkan pembobotan subkriteria dengan menggunakan ANP, subkriteria yang paling besar pengaruhnya dalam evaluasi supplier adalah harga penawaran sebesar 0,17227 . Selanjutnya, penentuan prioritas supplier dilakukan dengan menggunakan metode TOPSIS dan didapatkan urutan supplier untuk bahan baku kertas CD roll adalah supplier A, B, C, dan $\mathrm{D}$, sedangkan untuk bahan baku tinta web adalah supplier L, N, O, dan M.
\end{abstract}

Kata Kunci : evaluasi supplier; penentuan prioritas supplier; ANP; TOPSIS

\begin{abstract}
One of the factors that influence the company performance is the presence of suppliers which supplies raw materials. PT Masscom Graphy Semarang is a printing company which has cooperated with several suppliers to ensure continuity of production. Therefore, supplier performance evaluation conducted by the company is very important to obtain a reliable supplier in the supply of raw materials. The purpose of this research was to identify the supplier performance evaluation criteria and priorities of suppliers in accordance with the company's needs, and determined the priority order of the main raw material supplier for newspaper print. There was 17 sub-criteria used in evaluating the performance of suppliers and prioritization of suppliers. Analytical Network Process (ANP) can be used as an alternative to solve a problem that had many interrelated sub-criteria or influence in decision making. Furthermore, the method Technique For Orders Preference by Similarity to Ideal Solution (TOPSIS) was used for ranking suppliers. Based on the weighted sub-criteria by using ANP, the most influence subcriteria in determining the priority of suppliers offering price of 0.17227. Furthermore, to the supplier prioritization was done by using the TOPSIS method and obtained the order suppliers for raw materials paper roll was a supplier A, $B, C$, and $D$, while the raw material for the ink web was a supplier of $L, N, O$ and $M$.
\end{abstract}

Keywords: evaluation of suppliers; prioritization of suppliers; ANP; TOPSIS

\footnotetext{
${ }^{*}$ Penulis Korespondensi.

email: darminto_pujotomo@yahoo.com
}

Jurnal Teknik Industri, Vol. XI, No. 3, September 2016 


\section{Pendahuluan}

Supply Chain Management merupakan suatu pengelolaan aktifitas-aktifitas dalam rangka memperoleh bahan baku yang menjadi input di suatu perusahaan manufaktur kemudian diproses menjadi produk setengah jadi dan produk jadi yang selanjutnya produk tersebut dikirim kepada konsumen (Turban, 2008). Salah satu aktifitas yang mempengaruhi keberlangsungan proses produksi adalah pembelian bahan baku, dimana bahan baku ini diperoleh dari supplier. Saat ini makin banyak perusahaan manufaktur yang menyadari pentingnya peranan supplier dalam mendukung performansi rantai suplai mereka secara keseluruhan (Chen, 2011). Evaluasi dan pemilihan supplier menjadi salah satu peran fundamental dari purchasing. Karena dengan evaluasi dan pemilihan supplier yang tepat akan memberikan dapak langsung terhadap harga yang murah, kualitas yang baik, dan servis level yang memuaskan dari supplier (Amindoust et al., 2012).

PT Masscom Graphy Semarang (Masscom) merupakan perusahaan yang bergerak di bidang percetakan, dimana hasil produknya berupa koran harian suara merdeka. Bahan baku utama yang diperlukan untuk produksi cetak koran adalah kertas CD roll, dan tinta web. Untuk menjamin kelangsungan produksinya, Masscom telah menjalin kerjasama dengan beberapa supplier. Hal ini dilakukan untuk menjaga ketersediaan material demi kelancaran jalannya proses produksi. Untuk memenuhi kebutuhan produksi cetak koran, Masscom menggunakan 4 supplier (A, B, C, D) untuk bahan baku kertas, begitu pula untuk bahan baku tinta web, Masscom juga menggunakan 4 supplier (L, M, N, O).

Berdasarkan hasil penelitian awal berupa wawancara secara langsung dengan kepala bagian logistik menunjukkan bahwa dalam menjalankan proses pengadaan bahan baku, kerjasama yang terjalin antara PT Masscom Graphy Semarang dengan para supplier bahan baku kurang memuaskan perusahaan karena kinerja supplier yang belum stabil. Ketidakstabilan ditunjukkan dengan adanya keterlambatan pengiriman dan ketidaksesuaian kualitas pasokan dengan standar perusahaan

Permasalahan selanjutnya adalah dalam melakukan pemilihan supplier, selama ini Masscom hanya terbatas pada kriteria harga kualitas dan delivery saja. keadaan inilah yang mengarah pada pentingnya melakukan evaluasi kinerja supplier. Penentuan kriteria harga dan kualitas dilakukan untuk seluruh bahan baku. Kriteria tersebut dinilai belum sepenuhnya merepresentasikan kapabilitas dan kinerja dari supplier dalam menghasilkan unit yang diinginkan.

Untuk memenuhi target produksi koran setiap hari, perusahaan harus memiliki dukungan dari supplier yang handal dalam memasok bahan baku

Jurnal Teknik Industri, Vol. XI, No. 3, September 2016 utama cetak koran. Kehandalan supplier yang dibutuhkan tercermin pada supplier yang mampu memasok material berharga murah, berkualitas, tepat waktu, mampu memberikan sevice yang memuaskan (Yoserizal dan Singgih, 2012). Oleh karena itu, perusahaan perlu melakukan evaluasi kinerja supplier dengan menggunakan kriteria yang menilai juga responsiveness, service dan green supplier yang diberikan oleh supplier kepada perusahaan.

Penelitian ini bertujuan untuk mengidentifikasi kriteria evaluasi penentuan prioritas supplier yang sesuai dengan kebutuhan perusahaan, dan menentukan urutan prioritas supplier untuk PT Masscom Graphy Semarang berdasarkan evaluasi kinerja supplier. Pendekatan yang digunakan pada penelitian ini adalah metode Analytic Network Process (ANP) dikombinasikan dengan Technique for Order Preference by Similarity to Ideal Solution (TOPSIS). Dalam penelitian ini metode ANP digunakan untuk memperoleh bobot relatif dari masing-masing kriteria dan subkriteria. Sedangkan metode TOPSIS adalah teknik untuk urutan preferensi yang digunakan untuk merangking alternatif supplier. Metode ANP digunakan untuk pembobotan kriteria dan uji tingkat konsistensi terhadap matriks perbandingan berpasangan. Jika matriks telah konsisten maka dapat dilanjutkan ke metode TOPSIS untuk melakukan perankingan untuk menetukan alternatif supplier terpilih dengan menggunakan input bobot kriteria. Penelitian ini diharapkan dapat memberikan alternatif supplier yang sesuai dengan kriteria yang diperlukan perusahaan.

\section{Metodologi Penelitian}

Metodologi penelitian ini digunakan sebagai acuan dalam melakukan penelitian sehingga dapat berjalan dengan sistematis. Metodologi penelitian penelitian ini terdiri dari penentuan kriteria dan subkriteria, penentuan hubungan kriteria dan subkriteria, perancangan kuesioner, responden, penentuan bobot menggunakan metode ANP dan penentuan prioritas supplier menggunakan metode TOPSIS.

\section{Kriteria dan Subkriteria}

Kriteria yang digunakan berdasarkan penelitian dari Lee et al. (2009), Chen (2011), Gallego (2011), Lin et al. (2011) dan Yoserizal \& Singgih (2012). Setelah dilakukan wawancara dan diskusi dengan pihak pengambil keputusan, maka diperoleh 5 kriteria yang sesuai dengan karakter dan visi misi perusahaan yang kemudian akan digunakan dalam penelitian ini. Berikut adalah kriteria dan subkriteria yang digunakan dalam penelitian ini:

a. Quality, dengan subkriteria yaitu sertifikat terkait kualitas, ketepatan packaging, dan ketepatan kualitas. 
b. Price, dengan subkriteria yaitu harga bahan baku dan potongan harga (discount).

c. Delivery, dengan subkriteria lead time, flexibility, on time delivery, ketepatan jumlah pengiriman, dan lokasi geografis.

d. Service, dengan subkriteria yaitu waranties and claim policies, procedural compliance, responsiveness, communication system, dan keringanan waktu pembayaran.

e. Green supplier, dengan subkriteria green process dan internal control process.

2. Penentuan Hubungan Kriteria dan Subkriteria Penentuan hubungan saling ketergantungan dilakukan berdasarkan metode voting hasil penelitian oleh Kasirian dan Yusuff (2009). Hasil dari hubungan ketergantungan subkriteria. Jumlah responden $(\mathrm{N})$ adalah lima orang. Jika dalam suatu blok (baris $\mathrm{i}$ - kolom $\mathrm{j}$ ), jumlah responden yang memilih (Vij) lebih dari atau sama dengan $(\mathrm{N} / 2 \geq 2,5)$, maka terdapat hubungan keterkaitan antar kriteria tersebut. Dari hubungan ini, nantinya akan menjadi dasar dalam pembuatan model ANP dengan software super decision.

\section{Perancangan Kuesioner}

Pada penelitian ini terdapat 3 kuesioner yang digunakan, dimana ketiga kuesioner ini harus dilakukan secara berurutan. Kuesioner yang pertama disebarkan adalah kuesioner hubungan antar kriteria dan subkriteria. Kuesioner ini bertujuan untuk mengetahui hubungan ketergantungan antar subkriteria sebagai acuan dasar untuk membuat model ANP. Kuesioner yang kedua adalah kuesioner perbandingan berpasangan yang digunakan untuk mendapatkan bobot kepentingan tiap subkriteria. Kuesioner ini dibuat berdasarkan hubungan ketergantungan yang didapatkan dari kuesioner pertama Dan kuesioner ketigadigunakan untuk menentukan nilai judgement setiap subkriteria terhadap setiap alternatif yakni supplier dari tiap bahan baku.

\section{Responden}

Responden yang terlibat pada penelitian ini adalah kepala bagian logistik dan 2 staff bagian logistik yang bertugas khusus untuk melakukan pemilihan supplier, kepala bagian produksi, dan kepala bagian quality control. Responden ini dipilih karena dianggap menguasai dan memahami kegiatan pengadaan bahan baku di PT Masscom Graphy Semarang dari para supplier.

5. Penentuan Bobot Menggunakan Metode ANP Dalam melakukan pengolahan data berdasarkan hasil penilaian dari kuesioner yang disebarkan ke beberapa responden, berikut langkah-langkah perhitungannya dengan menggunakan Software Super Decision (Perera, Melon, Bautista, \& Ferrando, 2010):

a. Menghitung nilai geometric mean, tujuan dari perhitungan geometric mean ialah

Jurnal Teknik Industri, Vol. XI, No. 3, September 2016 mengkumulatifkan jawaban responden dalam sebuah formula untuk mendapatkan sebuah keputusan atau mendapatkan satu jawaban

b. Memasukkan hasil perhitungan mean geometric kedalam software super decision

c. Melakukan uji konsistensi, hasil kuesioner berpasangan akan diuji kekonsistenannya melihat nilai CR harus lebih kecil dari 0,1 . Suatu matriks perbandingan berpasangan akan konsisten bila indeks inkonsistensinya berada dibawah nilai 0,1 . Hal tersebut penting karena tanpa adanya ketidak konsistensian maka perubahan yang mempengaruhi tingkat preferensi tidak berlaku

d. Menentukan bobot kepentingan subkriteria. Bobot kepentingan subkriteria didapat dari menormalisasikan nilai limiting pada setiap elemen.

6. Penentuan Prioritas Supplier Menggunakan Metode TOPSIS

Setelah didapatkan bobot kepentingan untuk masing-masing subkriteria maka tahapan selanjutnya adalah meranking prioritas untuk alternatif supplier yang dianggap paling sesuai untuk PT Masscom Graphy Semarang. Pada penelitian ini, metode yang digunakan untuk merangking prioritas adalah dengan menggunakan metode TOPSIS. Metode ini dipilih karena dengan menggunakan TOPSIS, alternatif yang nantinya terpilih memiliki jarak terdekat dengan solusi ideal, dan jarak terjauh dengan solusi ideal negatif. Metode ini memiliki prinsip dasar yaitu bahwa alternatif yang terpilih haruslah memiliki jarak terdekat dari solusi ideal dan jarak terjauh dari solusi negatif-ideal Solusi ideal positif didefiniskan sebagai jumlah dari seluruh nilai terbaik yang dapat dicapai untuk setiap atribut, sedangkan solusi negatif-ideal terdiri dari seluruh nilai terburuk yang dapat dicapai untuk setiap atribut. TOPSIS mempertimbangkan keduanya, jarak terhadap solusi ideal positif dan terhadap solusi ideal negatif dengan mengambil kedekatan relatif terhadap solusi ideal positif. Adapun tahapan metode TOPSIS sebagai berikut (Kusumadewi, 2006):

a. Membuat sebuah matriks keputusan.

Membangun keputusan X mengacu terhadap $m$ alternatif yang akan dievaluasi berdasarkan $n$ kriteria. Matriks keputusan $\mathrm{X}$ dapat dilihat sebagai berikut:

$$
\begin{aligned}
& \begin{array}{llll}
x_{1} & x_{2} & \ldots & x_{n 1}
\end{array} \\
& \mathrm{X}=\stackrel{a_{1}}{a_{2}} \underset{\vdots}{a_{n}}\left[\begin{array}{cccc}
x_{11} & x_{12} & \cdots & x_{m 1} \\
x_{12} & x_{22} & \ldots & x_{m 2} \\
\vdots & \vdots & & \vdots \\
x_{m 1} & x_{m 2} & \cdots & x_{m n}
\end{array}\right] \ldots \ldots(1)
\end{aligned}
$$

Keterangan:

$a_{i}(\mathrm{i}=1,2,3, \ldots, \mathrm{m})$ adalah alternatifalternatif yang mungkin, 
$x_{j}(\mathrm{j}=1,2,3, \ldots, \mathrm{n})$ adalah atribut dimana performansi alternatif diukur,

$X_{i j}$ adalah performansi alternatif $a_{i}$ dengan acuan atribut .

b. Membuat matriks keputusan yang ternormalisasi.

Persamaan yang digunakan untuk mentransformasikan setiap elemen $\mathrm{x}_{\mathrm{ij}}$ adalah :

$$
r_{i j} \frac{x_{i j}}{\sqrt{\sum_{i=1}^{m} x_{i j}^{2}}} .
$$

dengan $\mathrm{i}=1,2,3, \ldots, \mathrm{m} ;$ dan $\mathrm{j}=1,2,3, ., \mathrm{n}$

c. Membuat matriks keputusan yang ternormalisasi tebobot.

Dengan bobot $w_{i}=\left(w_{1}, w_{2}, w_{3}, \ldots \ldots \ldots . . w_{n}\right)$, dimana $w_{i}$ adalah bobot dari kriteria ke-j dan $\sum_{i=1}^{n} w_{j}=1$, maka normalisasi bobot matriks $\mathrm{V}$ adalah :

$$
v_{i j}=w_{i} r_{i j}
$$

dengan $i=1,2, \ldots, \mathrm{m} ; \operatorname{dan} j=1,2,3, \ldots, \mathrm{n}$ dimana :

$v_{i j}=$ matriks ternormalisasi terbobot

$w_{i}=$ vektor bobot ke-i

d. Menentukan matriks solusi ideal positif dan solusi ideal negatif. Solusi ideal positif dinotasikan $A^{+}$, sedangkan solusi ideal negatif dinotasikan $A^{-}$. Solusi ideal positif $A^{+}$dan solusi ideal negatif $A^{-}$dapat ditentukan berdasarkan rating bobot ternormalisasi (yij) sebagai :

$$
\begin{aligned}
& y_{i j}=w_{i} r_{i j} \\
& A^{+}=\left(y_{1}^{+}, y_{2}^{+} \times \ldots \ldots y_{n}^{+}\right) \\
& A^{-}=\left(y_{1}^{-}, y_{2}^{-} \times \ldots \ldots y_{n}^{-}\right)
\end{aligned}
$$

Dengan :

$$
\begin{aligned}
& y_{j}^{+}=\left\{\begin{array}{cc}
\max y_{i j}, j i k a j \text { adalah atribut } \\
i & \text { keuntungan } \\
\min _{i} y_{i j} ; j i k a j \text { adalah atribut } & \text { biaya }
\end{array}\right. \\
& y_{j}^{-}=\left\{\begin{array}{cc}
\max y_{i j} ; j i k a j \text { adalah atribut } \\
i & \text { keuntungan } \\
\min _{i} & \text { biaya }
\end{array}\right.
\end{aligned}
$$

e. Menghitung separasi

1. $\mathrm{S}^{+}$adalah jarak alternative dari solusi ideal positif didefenisikan sebagai:

$$
S_{i}^{+}=\sqrt{\sum_{j=1}^{n}\left(v_{i j}-v_{j}^{+}\right)^{2}} \text {. }
$$

dengan $\mathrm{i}=1,2,3, \ldots \ldots . . \mathrm{m}$

2. $\mathrm{S}^{-}$adalah jarak alternative dari solusi ideal negative didefenisikan sebagai

$$
S_{i}^{-}=\sqrt{\sum_{j=1}^{n}\left(v_{i j}-v_{j}^{-}\right)^{2}}
$$

dengan $\mathrm{i}=1,2,3, \ldots \ldots . . \mathrm{m}$

f. Menghitung kedekatan terhadap solusi ideal positif.

Kedekatan relatif dari setiap alternative terhadap solusi ideal positif dapat dihitung dengan menggunakan persamaan berikut

$$
C_{i}^{+}=\frac{S_{i}^{-}}{\left(S_{i}^{-}+S_{i}^{+}\right)}, 0 \leq C_{i}^{+} \leq 1 \ldots .(8)
$$

g...Merangking aternatif.

Alternative diurutkan dari nilai $\mathrm{C}^{+}$terbesar ke nilai terkecil. Alternatif dengan nilai $\mathrm{C}^{+}$ terbesar merupakan solusi terbaik.

\section{Hasil Pengolahan Data}

Hasil dari penelitian adalah hubungan antar subkriteria evaluasi kinerja supplier, bobot kepentingan tiap subkriteria dan penentuan prioritas supplier untuk tiap bahan baku.

\section{Hubungan Ketergantungan Antar Subkriteria}

Berdasarkan hasil kuesioner pertama, dapat diidentifikasi ada atau tidaknya hubungan antar kriteria dan subkriteria dan dapat diidentifikasi hubungan inner dependence dan outer dependence dari masing-masing subkriteria. Dari hubungan keterkaitan antar subkriteria dan kriteria ini, dapat dibuat suatu model evaluasi kinerja supplier dan penentuan prioritas supplier PT Masscom Graphy Semarang yang mengacu pada metode Analytical Network Process. Hasil kuesioner hubungan keterkaitan antar subkriteria dapat dilihat pada Tabel 1. Pada tabel tersebut hubungan keterkaitan antar subkriteria ditunjukkan dengan kotak berwarna kuning, sebagai contoh, untuk subkriteria harga bahan baku (P1) pada bagian baris dan potongan harga (P2) pada bagian kolom memiliki nilai 3, dimana sebanyak 3 dari 5 responden menyatakan ada pengaruh dari P1 terhadap P2, maka dapat disimpulkan bahwa terdapat hubungan antara subkriteria harga bahan baku dengan subkriteria potongan harga.

\section{Bobot Kepentingan Tiap Subkriteria}

Penentuan bobot kepentingan tiap subkriteria pada penelitian ini menggunakan metode Analytical Network Process (ANP). Dalam menggunakan metode ANP dibutuhkan kerangka ANP. Dimana kerangka ANP dibuat dengan menggunakan software super decision dan dapat didesain setelah mengetahui hubungan antar subkriteria. Pembuatan kerangka ANP disesuaikan dengan hubungan antar subkriteria tersebut. Kerangka ANP pada penelitian ini dapat dilihat pada Gambar 1 dan Gambar 2. 
Tabel 1. Rekapitilasi Kuesioner Hubungan Keterkaitan Antar Subkriteria

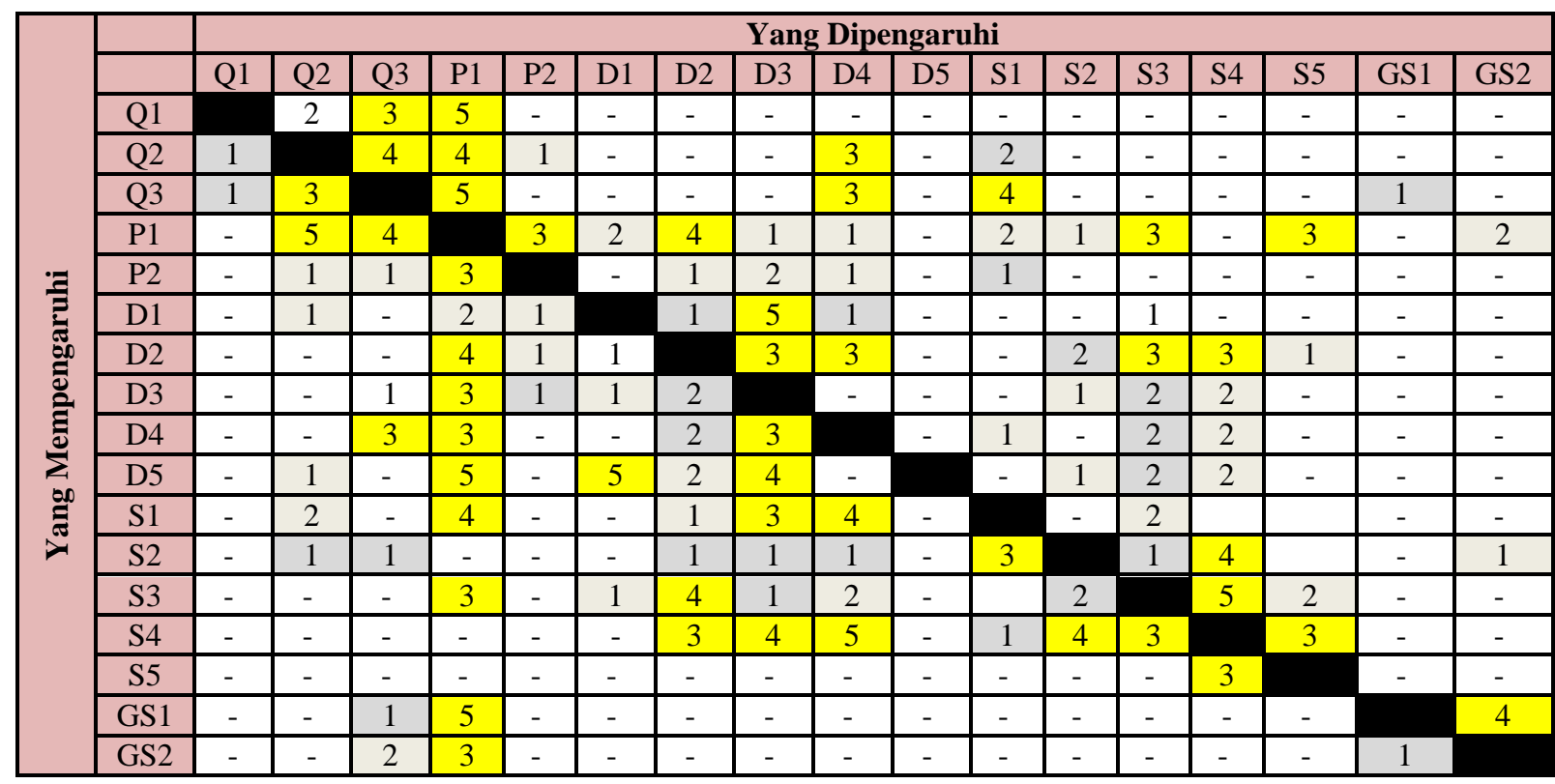

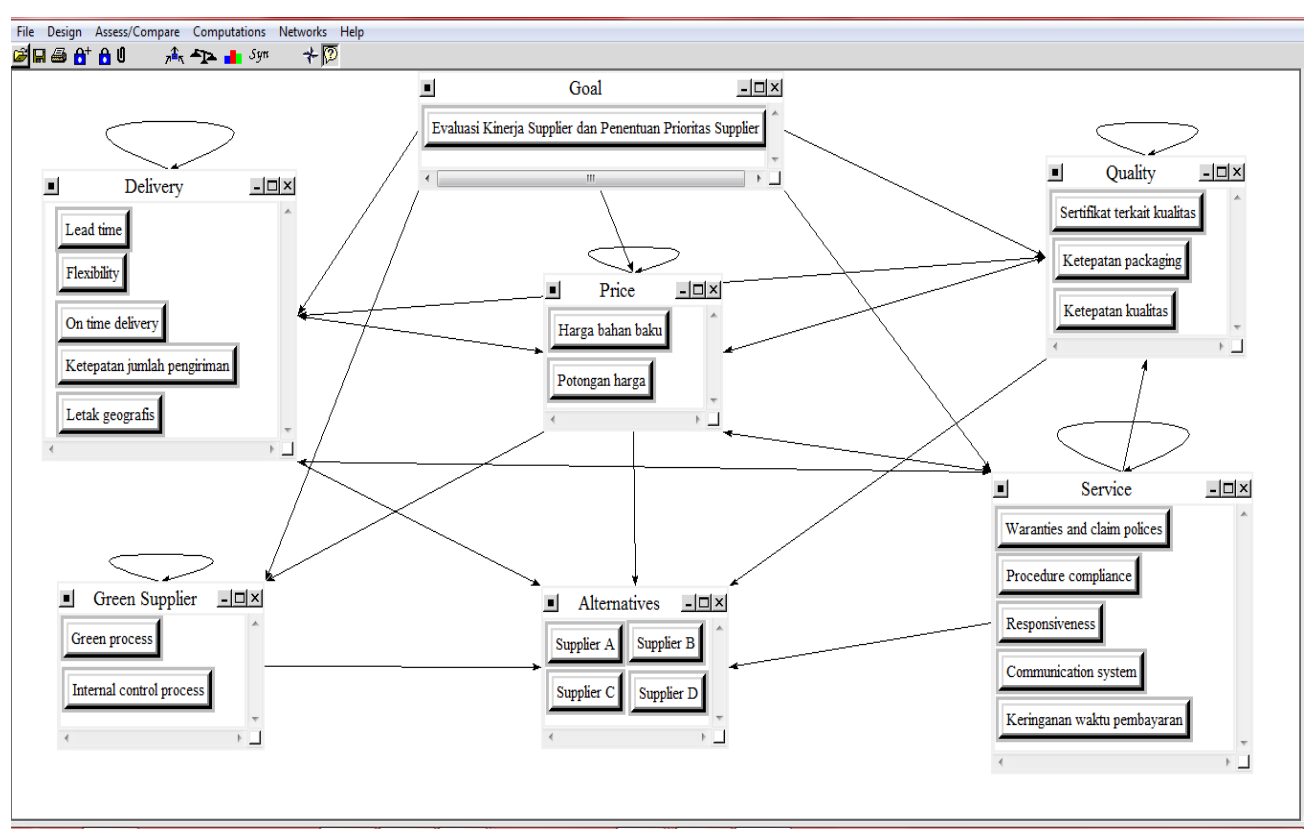

Gambar 1. Kerangka ANP (Kertas CD roll)

Gambar 1 dan Gambar 2 menunjukkan keterkaitan subkriteria dalam satu kriteria (inner dependence) dan antar kriteria (outer dependence). Keterkaitan antar subkriteria tersebut digunakan untuk menyusun kuesioner perbandingan berpasangan antar subkriteria dan kriteria.

Untuk mendapatkan bobot kepentingan tiap subkriteria, hal pertama yang dilakukan adalah menghitung mean geometric yang bertujuan mengkumulatifkan jawaban responden (jika lebih dari satu) dalam sebuah formula untuk mendapatkan sebuah keputusan. Hal yang perlu diperhatikan dalam

Jurnal Teknik Industri, Vol. XI, No. 3, September 2016 mengolah data menggunakan ANP adalah nilai inconsistency harus kurang dari 0,1. Apabila nilai inconsistency yang diperoleh menunjukkan nilai lebih dari 0,1 , maka matriks perbandingan berpasangan tidak konsisten sehingga dibutuhkan perbaikan dalam pengambilan keputusan perbandingan berpasangan. Dari hasil pengecekan inconsistency dengan software super decision, dapat disimpulkan bahwa matriks perbandingan berpasangan sudah konsisten, sehingga tidak diperlukan perbaikan dalam pengambilan keputusan perbandingan berpasangan. 


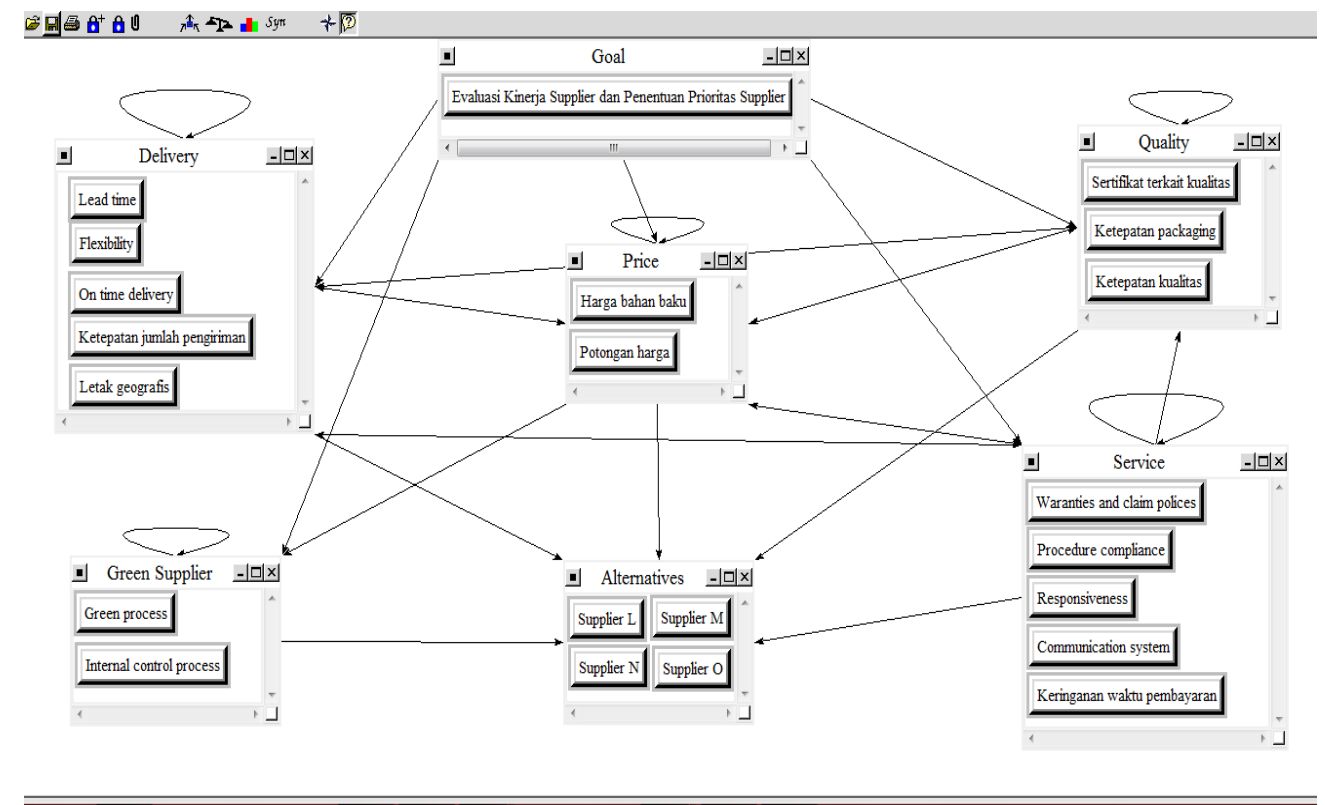

Gambar 2. Kerangka ANP (Tinta web)

Hasil rekapitulasi output bobot kepentingan tiap subkriteria dapat dilihat pada Tabel 2. Nilai bobot kepentingan untuk setiap subkriteria terdapat pada kolom normalized by all element, dimana nilai bobot kepentingan tiap subkriteria digunakan sebagai data input untuk perhitungan dengan metode TOPSIS.

Penentuan Prioritas Alternatif Terpilih dengan Metode Technique for order preference by similarity to an ideal solution (TOPSIS)

1. Membuat Matriks Keputusan

Matriks Keputusan didapat dari perhitungan hasil kuesioner yaitu dengan cara merata-rata hasil kuesioner yang dibagikan kepada responden. Hasil mariks keputusan dilihat pada Tabel 3.

2. Normalisasi Matriks Keputusan

Tahap selanjutnya adalah menghitung matriks keputusan normal. Nilai normalisasi dihitung dengan menggunakan persamaan 2. Normalisasi matriks keputusan dapat dilihat padaTabel 4.

3. Matriks keputusan normalisasi terbobot

Tahap selanjutnya, setelah melakukan perhitungan normalisasi matriks keputusan langkah selanjutnya adalah membuat matriks keputusan normalisasi terbobot dengan menggunakan bobot kepentingan setiap subkriteria pada Tabel 2. Nilai normalisasi dihitung dengan menggunakan persamaan 3 . Matriks keputusan normalisasi terbobot dapat dilihat pada Tabel 5.

4. Menghitung Solusi ideal

Tahap selanjutnya adalah menghitung solusi ideal positif daan solusi ideal negatif. Perhitungan solusi ideal dengan menggunakan persamaan 4 dan 5 dengan berdasarkan matriks keputusan ternormalisasi terbobot pada Tabel 4. Solusi ideal positif dan negatif dapat dilihat pada Tabel 6.

5. Menetukan Separasi

Tahap selanjutnya adalah menghitung separasi/jarak antara nilai terbobot setiap alternatif. Perhitungan jarak antara nilai terbobot setiap alternatif berdasarkan persamaan 6 dan 7 . Perhitungan separasi atau jarak dilakukan dengan tujuan untuk menentukan kedekatan relatif dari setiap alternatif (supplier) dengan solusi optimal.

Hasil perhitungan jarak antara nilai terbobot setiap alternatif (supplier) terhadap solusi ideal positif dan negatif untuk baku kertas CD roll

Supplier $A^{+}=0,0310$

Supplier $B^{+}=0,0354$

Supplier $C^{+}=0,0619$

Supplier $D^{+}=0,0612$

Supplier $A^{-}=0,0586$

Supplier $B^{-}=0,0519$

Supplier $C^{-}=0,0338$

Supplier $D^{-}=0,0177$

Hasil perhitungan jarak antara nilai terbobot setiap alternatif (supplier) terhadap solusi ideal positif dan negatif untuk bahan baku tinta web adalah :

Supplier $L^{+}=0,0428$

Supplier $M^{+}=0,0755$

Supplier $N=0,0521$

Supplier $O^{+}=0,0601$

Supplier $L^{-}=0,0820$

Supplier $M^{-}=0,0366$

Supplier $N^{-}=0,0565$

Supplier $\mathrm{O}^{-}=0,0435$ 
6. Alternatif Strategi

Langkah Selanjutnya adalah menghitung setiap alternatif terhadap solusi ideal. Nilai kedekatan dihitung dengan menggunakan persamaan 8 .

Hasil perhitungan kedekatan relatif setiap alternatif (supplier) antara nilai terbobot, untuk bahan baku kertas CD roll terhadap solusi ideal positif dan solusi ideal negatif adalah :

Supplier $A=0,6470$

Supplier $B=0,5949$

Supplier $C=0,3531$

Supplier $D=0,2247$
Urutan prioritas untuk supplier baku kertas CD roll antara lain A, B, C, dan D.

Hasil perhitungan kedekatan relatif setiap alternatif (supplier) antara nilai terbobot, untuk bahan baku tinta web terhadap solusi ideal positif dan solusi ideal negatif adalah:

Supplier $L=0,6574$

Supplier $M=0,3267$

Supplier $N=0,5204$

Supplier $O=0,4198$

Urutan prioritas untuk supplier bahan baku tinta web antara lain L, N, O, dan M.

Tabel 2. Rekapitulasi Bobot Kepentingan Subkritria

\begin{tabular}{llll}
\hline Kriteria & Subkriteria & Limiting & $\begin{array}{l}\text { Normalized by } \\
\text { all element }\end{array}$ \\
\hline \multirow{3}{*}{ Quality } & Sertifikat terkait kualitas & 0,05514 & 0,07254 \\
& Ketepatan packaging & 0,03163 & 0,04161 \\
Kost & Hargatan kualitas & 0,07530 & 0,09906 \\
& Potongan harga (Diskon) & 0,13095 & 0,17227 \\
Delivery & Lead Time & 0,02063 & 0,02714 \\
& Flexibility & 0,00368 & 0,00484 \\
Delivery & On time delivery & 0,10984 & 0,14451 \\
& Ketepatan jumlah pengiriman & 0,01317 & 0,01732 \\
Service & Lokasi geografis & 0,03361 & 0,04421 \\
& Waranties and claim policies & 0,00837 & 0,01511 \\
& Procedure compliance & 0,02918 & 0,01101 \\
& Responsiveness & 0,0983 & 0,03839 \\
Green supplier & Communication system & 0,09581 & 0,12933 \\
& Keringanan waktu pembayaran & 0,00793 & 0,12605 \\
& Green process & 0,02809 & 0,01043 \\
& Internal control process & 0,007 & 0,03695 \\
& Jumlah & $\mathbf{0 , 7 6 0 1}$ & 0,00921 \\
\hline
\end{tabular}

Tabel 3. Matriks Keputusan

\begin{tabular}{|c|c|c|c|c|c|c|c|c|}
\hline \multirow{2}{*}{ Subkriteria } & \multicolumn{4}{|c|}{ Supplier (Kertas) } & \multicolumn{4}{|c|}{ Supplier (Tinta) } \\
\hline & $\mathbf{A}$ & B & $\mathbf{C}$ & D & $\mathbf{L}$ & M & $\mathbf{N}$ & $\mathbf{O}$ \\
\hline Sertifikat terka & 4,00 & 4,00 & 3,00 & 3,00 & 3,40 & 3,40 & 3,00 & 3,00 \\
\hline Ketepatan packaging & 00 & 4,40 & 2,40 & 3,00 & 3,80 & 3,60 & 2,80 & 3,20 \\
\hline Ketepatan kualitas & 3,60 & 4,20 & 3,00 & 2,60 & 3,60 & 3,60 & 2,80 & 2,40 \\
\hline Harga bahan baku & 3,20 & 3,20 & 4,20 & 3,00 & 2,40 & 3,40 & 4,00 & 3,00 \\
\hline Potongan harga (Di & 1,60 & 3,20 & 4,00 & 2,60 & 2,40 & 2,00 & 3,00 & 2,40 \\
\hline Lead Time & 3,40 & 3,60 & 2,00 & 2,40 & 3,00 & 2,40 & 3,00 & 3,00 \\
\hline Flexibility & 3,00 & 3,20 & 2,00 & 2,00 & 3,20 & 1,60 & 2,40 & 2,20 \\
\hline On time deliver & 3,60 & 3,60 & 2,40 & 2,80 & 3,60 & 2,80 & 2,40 & 3,00 \\
\hline Ketepatan jumlah & 3,40 & 4,40 & 2,40 & 3,00 & 4,00 & 3,00 & 2,00 & 3,40 \\
\hline Lokasi geog & 2,00 & 3,00 & 4,20 & 2,00 & 3,40 & 2,40 & 5,00 & 2,60 \\
\hline Waranties and clai & 2,60 & 4,00 & 3,40 & 2,20 & 3,00 & 3,20 & 2,60 & 3,00 \\
\hline Procedure compliance & 3,40 & 3,40 & 2,20 & 2,60 & 3,40 & 2,80 & 2,40 & 3,00 \\
\hline Responsiveness & 4,00 & 3,00 & 2,20 & 2,80 & 3,60 & 1,60 & 2,00 & 3,00 \\
\hline Communication s & 3,60 & 3,00 & 2,60 & 3,00 & 4,00 & 2,80 & 3,40 & 2,20 \\
\hline Keringanan waktu pembayaran & 2,00 & 3,40 & 4,20 & 3,00 & 2,60 & 4,00 & 5,00 & 3,60 \\
\hline Green process & 3,40 & 3,80 & 2,40 & 3,00 & 3,60 & 2,00 & 2,80 & 2,40 \\
\hline Internal control process & 3,20 & 3,80 & 2,40 & 3,00 & 3,00 & 2,60 & 2,20 & 2,80 \\
\hline
\end{tabular}

Jurnal Teknik Industri, Vol. XI, No. 3, September 2016 
Tabel 4. Normalisasi Matriks Keputusan

\begin{tabular}{lcccccccc}
\hline \multirow{2}{*}{ Subkriteria } & \multicolumn{4}{c}{ Supplier (Kertas) } & \multicolumn{4}{c}{ Supplier (Tinta) } \\
\cline { 2 - 9 } & $\mathbf{A}$ & $\mathbf{B}$ & $\mathbf{C}$ & $\mathbf{D}$ & $\mathbf{L}$ & $\mathbf{M}$ & $\mathbf{N}$ & $\mathbf{O}$ \\
\hline Sertifikat terkait kualitas & 0,5657 & 0,5657 & 0,4243 & 0,4243 & 0,5302 & 0,5302 & 0,4678 & 0,4678 \\
Ketepatan packaging & 0,5650 & 0,6215 & 0,3390 & 0,4238 & 0,5635 & 0,5338 & 0,4152 & 0,4745 \\
Ketepatan kualitas & 0,5287 & 0,6168 & 0,4406 & 0,3819 & 0,5727 & 0,5727 & 0,4454 & 0,3818 \\
Harga bahan baku & 0,4662 & 0,4662 & 0,6119 & 0,4370 & 0,3689 & 0,5226 & 0,6149 & 0,4612 \\
Potongan harga (Diskon) & 0,2683 & 0,5366 & 0,6708 & 0,4360 & 0,4847 & 0,4039 & 0,6058 & 0,4847 \\
Lead Time & 0,5807 & 0,6149 & 0,3416 & 0,4099 & 0,5241 & 0,4193 & 0,5241 & 0,5241 \\
Flexibility & 0,5748 & 0,6131 & 0,3832 & 0,3832 & 0,6615 & 0,3308 & 0,4961 & 0,4548 \\
On time delivery & 0,5727 & 0,5727 & 0,3818 & 0,4454 & 0,6037 & 0,4695 & 0,4025 & 0,5031 \\
Ketepatan jumlah pengiriman & 0,5031 & 0,6510 & 0,3551 & 0,4439 & 0,6281 & 0,4711 & 0,3140 & 0,5339 \\
Lokasi geografis & 0,3398 & 0,5097 & 0,7136 & 0,3398 & 0,4853 & 0,3426 & 0,7137 & 0,3711 \\
Waranties and claim policies & 0,4155 & 0,6392 & 0,5433 & 0,3516 & 0,5071 & 0,5409 & 0,4395 & 0,5071 \\
Procedure compliance & 0,5770 & 0,5770 & 0,3734 & 0,4412 & 0,5817 & 0,4791 & 0,4106 & 0,5133 \\
Responsiveness & 0,6516 & 0,4887 & 0,3584 & 0,4561 & 0,6741 & 0,2996 & 0,3745 & 0,5618 \\
Communication system & 0,5862 & 0,4885 & 0,4233 & 0,4885 & 0,6306 & 0,4414 & 0,5360 & 0,3468 \\
Keringanan waktu pembayaran & 0,3079 & 0,5234 & 0,6465 & 0,4618 & 0,3337 & 0,5133 & 0,6417 & 0,4620 \\
Green process & 0,5326 & 0,5952 & 0,3759 & 0,4699 & 0,6512 & 0,3618 & 0,5065 & 0,4341 \\
Internal control process & 0,5095 & 0,6051 & 0,3822 & 0,4777 & 0,5625 & 0,4875 & 0,4125 & 0,5250 \\
\hline
\end{tabular}

Tabel 5. Matriks Keputusan Normalisasi Terbobot

\begin{tabular}{ccccccccc}
\hline Subkriteria & \multicolumn{4}{c}{ Supplier (Kertas) } & \multicolumn{4}{c}{ Supplier (Tinta) } \\
\cline { 2 - 9 } & $\mathbf{A}$ & $\mathbf{B}$ & $\mathbf{C}$ & $\mathbf{D}$ & $\mathbf{L}$ & $\mathbf{M}$ & $\mathbf{N}$ & $\mathbf{O}$ \\
\hline Sertifikat terkait kualitas & 0,0410 & 0,0410 & 0,0308 & 0,0308 & 0,0385 & 0,0385 & 0,0339 & 0,0339 \\
Ketepatan packaging & 0,0235 & 0,0259 & 0,0141 & 0,0176 & 0,0234 & 0,0222 & 0,0173 & 0,0197 \\
Ketepatan kualitas & 0,0524 & 0,0611 & 0,0436 & 0,0378 & 0,0567 & 0,0567 & 0,0441 & 0,0378 \\
Harga bahan baku & 0,0803 & 0,0803 & 0,1054 & 0,0753 & 0,0636 & 0,0900 & 0,1059 & 0,0794 \\
Potongan harga (Diskon) & 0,0073 & 0,0146 & 0,0182 & 0,0118 & 0,0132 & 0,0110 & 0,0164 & 0,0132 \\
Lead Time & 0,0028 & 0,0030 & 0,0017 & 0,0020 & 0,0025 & 0,0020 & 0,0025 & 0,0025 \\
Flexibility & 0,0831 & 0,0886 & 0,0554 & 0,0554 & 0,0956 & 0,0478 & 0,0717 & 0,0657 \\
On time delivery & 0,0099 & 0,0099 & 0,0066 & 0,0077 & 0,0105 & 0,0081 & 0,0070 & 0,0087 \\
Ketepatan jumlah pengiriman & 0,0222 & 0,0288 & 0,0157 & 0,0196 & 0,0278 & 0,0208 & 0,0139 & 0,0236 \\
Lokasi geografis & 0,0051 & 0,0077 & 0,0108 & 0,0051 & 0,0073 & 0,0052 & 0,0108 & 0,0056 \\
Waranties and claim policies & 0,0046 & 0,0070 & 0,0060 & 0,0039 & 0,0056 & 0,0060 & 0,0048 & 0,0056 \\
Procedure compliance & 0,0222 & 0,0222 & 0,0143 & 0,0169 & 0,0223 & 0,0184 & 0,0158 & 0,0197 \\
Responsiveness & 0,0843 & 0,0632 & 0,0464 & 0,0590 & 0,0872 & 0,0387 & 0,0484 & 0,0727 \\
Communication system & 0,0739 & 0,0616 & 0,0534 & 0,0616 & 0,0795 & 0,0556 & 0,0676 & 0,0437 \\
Keringanan waktu pembayaran & 0,0032 & 0,0055 & 0,0067 & 0,0048 & 0,0035 & 0,0054 & 0,0067 & 0,0048 \\
Green process & 0,0197 & 0,0220 & 0,0139 & 0,0174 & 0,0241 & 0,0134 & 0,0187 & 0,0160 \\
Internal control process & 0,0047 & 0,0056 & 0,0035 & 0,0044 & 0,0052 & 0,0045 & 0,0038 & 0,0048 \\
\hline
\end{tabular}

Tabel 6. Solusi Ideal Positif dan Solusi Ideal Negatif

\begin{tabular}{ccccc}
\hline \multirow{2}{*}{ Subkriteria } & \multicolumn{2}{c}{ Kertas } & \multicolumn{2}{c}{ Tinta } \\
\cline { 2 - 5 } & $\left(\mathbf{A}^{+}\right)$ & $\mathbf{( \mathbf { A } ^ { - } )}$ & $\left.\mathbf{( A}^{+}\right)$ & $\left.\mathbf{( A}^{-}\right)$ \\
\hline Sertifikat terkait kualitas & 0,0410 & 0,0308 & 0,0385 & 0,0339 \\
Ketepatan packaging & 0,0259 & 0,0141 & 0,0234 & 0,0173 \\
Ketepatan kualitas & 0,0611 & 0,0378 & 0,0567 & 0,0378 \\
Harga bahan baku & 0,1054 & 0,0753 & 0,1059 & 0,0636 \\
Potongan harga (Diskon) & 0,0182 & 0,0073 & 0,0164 & 0,0110 \\
Lead Time & 0,0030 & 0,0017 & 0,0025 & 0,0020 \\
Flexibility & 0,0886 & 0,0554 & 0,0956 & 0,0478 \\
On time delivery & 0,0099 & 0,0066 & 0,0105 & 0,0070 \\
Ketepatan jumlah pengiriman & 0,0288 & 0,0157 & 0,0278 & 0,0139
\end{tabular}

Jurnal Teknik Industri, Vol. XI, No. 3, September 2016 


\begin{tabular}{ccccc} 
Lokasi geografis & 0,0108 & 0,0051 & 0,0108 & 0,0052 \\
Waranties and claim policies & 0,0070 & 0,0039 & 0,0060 & 0,0048 \\
Procedure compliance & 0,0222 & 0,0143 & 0,0223 & 0,0158 \\
Responsiveness & 0,0843 & 0,0464 & 0,0872 & 0,0387 \\
Communication system & 0,0739 & 0,0534 & 0,0795 & 0,0437 \\
Keringanan waktu pembayaran & 0,0067 & 0,0032 & 0,0067 & 0,0035 \\
Green process & 0,0220 & 0,0139 & 0,0241 & 0,0134 \\
Internal control process & 0,0056 & 0,0035 & 0,0052 & 0,0038 \\
\hline
\end{tabular}

\section{Pembahasan}

Bobot kepentingan subkriteria pada dasarnya menunjukkan urutan prioritas atau pengaruh subkriteria dalam evaluasi dan penentuan prioritas supplier. Semakin besar bobot suatu subkriteria maka semakin tinggi prioritas atau semakin besar pengaruh subkriteria tersebut dalam proses evaluasi dan penentuan prioritas supplier, dan sebaliknya. Output dari software super decisions menunjukan nilai bobot tertinggi adalah subkriteria harga bahan baku yakni sebesar 0,17227. Bobot kepentingan tertinggi kedua adalah subkriteria flexibility yakni sebesar 0,14451 dan kemudian diikuti subkriteria responsiveness yakni sebesar 0,12933, communication system yakni sebesar 0,12605 dan bobot kepentingan tertinggi kelima ketepatan kualitas yakni sebesar 0,09906. Urutan lima tertinggi prioritas bobot subkriteria ini, dapat dikatakan sangat mempengaruhi perusahaan dalam melakukan evaluasi kinerja supplier dan penentuan prioritas supplier.

Hasil penentuan prioritas bobot subkriteria dengan metode ANP dapat digunakan bagi Masscom sebagai dasar dalam melakukan evaluasi dan penentuan prioritas supplier. Evaluasi dan penentuan prioritas supplier yang sesuai dengan kriteria yang diinginkan oleh perusahaan dapat menjamin pasokan bahan baku dengan spesifikasi bahan baku yang sesuai dengan kebutuhan perusahaan, baik dalam tingkat kualitas, harga, delivery (waktu dan jumlah pengirimannya), dan tingkat service yang diberikan oleh supplier. Selain itu risiko pun dapat diminimalisir sehingga memperlancar arus produksi dan mengurangi biaya produksi perusahaan.

Berdasarkan hasil penilaian responden pada tiap subkriteria terhadap kinerja supplier dengan metode TOPSIS, maka dapat diketahui kelemahan dan keunggulan kinerja dari masing-masing supplier, sehingga masukan atau saran dapat diberikan kepada setiap supplier bahan baku kertas dan tinta. Pada bahan baku kertas, masukan atau saran yang dapat diberikan kepada supplier A adalah supplier A perlu memberikan potongan harga dan keringanan waktu pembayaran kepada perusahaan karena harga bahan baku kertas dari supplier A cukup tinggi sehingga perusahaan juga menuntut kepada supplier untuk memberikan potongan harga terhadap pengadaan bahan baku dengan jumlah tertentu, dan perusahaan juga akan meminta kepada supplier untuk memberikan tenggang waktu pembayaran sehingga

pembayaran bahan baku tidak dilakukan dengan cash. Masukan atau saran yang dapat diberikan kepada supplier B adalah supplier B perlu mempertahankan kinerjanya yang sudah baik karena supplier B unggul dibeberapa subkriteria, dan supplier B perlu meningkatkan kinerjanya dalam hal comminication system dan responsiveness. Sedangkan untuk supplier C perlu meningkatkan kinerjanya dalam hal delivery, karena kriteria ini menjadi kriteria yang sangat penting dan mempunyai bobot kepentingan yang tinggi dalam evaluasi dan penentuan prioritas supplier pada PT Masscom Graphy Semarang. Supplier D perlu meningkatkan kinerjanya dalam hal quality, karena kriteria quality juga menjadi kriteria yang sangat penting dan mempunyai bobot kepentingan yang cukup tinggi dalam evaluasi dan penentuan prioritas supplier pada PT Masscom Graphy Semarang.

Pada bahan baku tinta, masukan atau saran yang dapat diberikan kepada supplier $\mathrm{L}$ adalah sama halnya dengan supplier A pada bahan baku kertas, supplier L perlu memberikan potongan harga dan keringanan waktu pembayaran kepada perusahaan karena harga bahan baku kertas dari supplier L cukup tinggi sehingga perusahaan juga menuntut kepada supplier untuk memberikan potongan harga terhadap pengadaan bahan baku dengan jumlah tertentu, dan perusahaan juga akan meminta kepada supplier untuk memberikan tenggang waktu pembayaran sehingga pembayaran bahan baku tidak dilakukan dengan cash. Masukan atau saran yang dapat diberikan kepada supplier $\mathrm{M}$ adalah supplier $\mathrm{M}$ perlu meningkatkan kinerjanya dalam hal delivery, karena kriteria ini menjadi kriteria yang sangat penting dan mempunyai bobot kepentingan yang tinggi dalam evaluasi dan penentuan prioritas supplier pada PT Masscom Graphy Semarang. Supplier $\mathrm{N}$ adalah supplier $\mathrm{N}$ perlu meningkatkan kinerjanya dalam hal delivery dan service yaitu pada subkriteria on time delivery, ketepatan jumlah pengiriman, waranties and claim policies dan procedure compliance. Sedangkan supplier $\mathrm{O}$ perlu memperbaiki sistem komunikasi yang terjalin dengan PT Masscom Graphy Semarang karena sistem komunikasi menjadi subkriteria yang sangat penting dan mempunyai bobot kepentingan yang tinggi dalam evaluasi dan penentuan prioritas supplier pada PT Masscom Graphy Semarang dan subkriteria komunikasi sistem juga banyak mempengaruhi subkriteria yang lain sehingga apabila 
sistem komunikasi antara supplier dengan perusahaan baik maka delivery, quality dan service yang diberikan kepada perusahaan juga akan baik dan sesuai dengan keinginan dan kebutuhan perusahaan.

Hasil urutan prioritas supplier antara hasil penelitian dengan menurut PT Masscom Graphy Semarang terdapat perbedaan. Hal ini dikarenakan penentuan prioritas supplier yang telah diterapkan oleh PT Masscom Graphy Semarang hanya berdasarkan pada kritera harga, kualitas bahan baku, dan delivery yang diberikan setiap supplier, sedangkan pada penelitian ini menggunakan 5 kriteria dengan 17 subkriteria.

Evaluasi kinerja supplier ini bersifat berkala, perusahaan dapat sewaktu-waktu menilai performa supplier. Hasil evaluasi dapat dijadikan usulan keputusan oleh pihak bagian operasional untuk menentukan jumlah pemesanan bahan baku karena akan terpengaruh dari performa masing-masing supplier. Supplier yang memiliki performa lebih bagus dari supplier lainnya akan mendapatkan jumlah pesanan yang lebih banyak. Berdasarkan hasil evaluasi supplier, memberikan hasil bahwa suluruh supplier dapat dinyatakan lolos evaluasi walaupun dengan performansi yang berbeda-beda.

\section{Kesimpulan}

Identifikasi kriteria dan subkriteria untuk evaluasi supplier yang dapat mempengaruhi penentuan prioritas supplier bahan baku pada PT Masscom Graphy Semarang disesuaikan dengan keadaan empirik di perusahaan. Dimana terdapat 17 subkriteria dari 5 kriteria yang mempengaruhi evaluasi supplier dan penentuan prioritas supplier bahan baku pada PT Masscom Graphy Semarang diantaranya adalah sertifikat terkait kualitas, ketepatan packaging, dan ketepatan kualitas yang dirangkum dalam kriteria quality, harga bahan baku, dan potongan harga (discount) yang dirangkum dalam kriteria price, lead time, flexibility, on time delivery, ketepatan jumlah pengiriman, dan lokasi geografis yang dirangkum dalam kriteria delivery, waranties and claim policies, procedure compliance, responsiveness, communication system, dan keringanan waktu pembayaran yang dirangkum dalam kriteria service, green process, dan internal control process yang dirangkum dalam kriteria green supplier.

Pembobotan kepentingan setiap subkriteria dalam evaluasi kinerja supplier di PT Masscom Graphy Semarang diperoleh dengan menggunakan metode ANP, didapat urutan nilai bobot kepentingan paling tinggi hinga terendah pada subkriteria evaluasi kinerja supplier di PT Masscom Graphy adalah harga bahan baku, selanjutnya flexibility, kemudian responsiveness, communication system, ketepatan kualitas, sertifikat terkait kualitas, ketepatan jumlah pengiriman, ketepatan packaging, procedure compliance, green process, potongan harga, on time delivery, lokasi geografis, waranties and claim policies, keringanan waktu pembayaran, internal control process, dan lead time

Penentuan prioritas supplier bahan baku di PT Masscom Graphy Semarang dilakukan dengan menggunakan metode TOPSIS. Urutan prioritas supplier untuk bahan baku kertas CD roll diantaranya adalah supplier A, supplier B, supplier C, dan supplier D. Sedangkan untuk bahan baku tinta web diantaranya adalah supplier L, supplier $\mathrm{N}$, supplier $\mathrm{O}$, dan supplier $\mathrm{M}$.

\section{Daftar Pustaka}

Amindoust, A., Ahmed, S., \& Saghafinia, A. (2012). Supplier Selection and Performance Evaluation of Telecommunication Company. American J. of Engineering and Applied Sciences, Vol. 5 No. 1, 49-52.

Chen, Y. J. (2011). Structured methodology for supplier selection and evaluation in a supply chain. Information Sciences 181, 1651-1670.

Gallego, L. V. (2011). Review of Existing Methods, Models, and Tools for Supplier Evaluation. Departement of Management ang Engineering Linkopings Universitet.

Kasirian, M. D., \& Yusuff, R. D. (2009). Determining Interdependencies Among Supplier Selection Criteria. European Journal of Scientific Research, Vol.35 No.1, 76-84.

Kusumadewi, S. (2006). Fuzzy Multi-Atribut Decision Making (Fuzzy MADM). Yogyakarta: Graha Ilmu.

Lee, A.H.I., Kang, H.Y., Hsu, C.F., \& Hung, H.C. (2009). A green supplier selection model for high-tech industry. An International Journal Expert Systems with Applications, Vol. 36, 7917-7927.

Lin, C. T., Chen, C. B., \& Ting, Y. C. (2011). An ERP Model for Supplier Selection in Electronics Industry. An International Journal Expert Systems with Applications, Vol. 38, 1760-1765

Perera, A. S., Melon, M. G., Bautista, R. P., \& Ferrando, J. P. P. (2010). A Project Strategic Index Proposal for Portfolio Selection in Electrical Company based on the Analytic Network Process. Renewable and Sustainable Energy Reviews Vol.14, 1569-1579.

Turban, E., Ting-Peng Liang, Aronson. (2008). Decision Support System and Intelligent System. Yogyakarta: Andi.

Yoserizal, Y., \& Singgih, M. L. (2012). Integrasi Metode Dematel (Decision Making Trial And Evaluation Laboratory) dan ANP (Analytic Network Process) dalam Evaluasi Kinerja Supplier Di PT. XYZ. Prosiding Seminar Nasional Manajemen Teknologi, XV. 